\title{
Pre-Procedural Glucose Levels and the Risk for Contrast-Induced Nephropathy in Diabetic Patients Undergoing Coronary angiography or Percutaneous Coronary Intervention
}

\author{
Hong Zhang \\ Tianjin Chest Hospital \\ Han Fu \\ Tianjin Medical University \\ Peng Zhang \\ Tianjin Chest Hospital \\ Shicheng Yang \\ Tianjin Chest Hospital \\ Naikuan Fu ( $\sim$ cdrfnk@163.com ) \\ Tianjin Chest Hospital
}

\section{Research Article}

Keywords: diabetes mellitus, pre-procedural glucose, percutaneous coronary intervention, contrastinduced nephropathy, risk factors

Posted Date: March 13th, 2021

DOl: https://doi.org/10.21203/rs.3.rs-285008/v1

License: (c) (1) This work is licensed under a Creative Commons Attribution 4.0 International License. Read Full License 


\section{Abstract}

Diabetes mellitus is an independent risk factor for Contrast-induced nephropathy $(\mathrm{CIN})$ in patients undergoing Coronary arteriography (CAG)/percutaneous coronary intervention (PCl). This study aimed to evaluate whether pre-procedural glucose levels in diabetic patients who received $\mathrm{CAG} / \mathrm{PCl}$ had an impact on the occurrence of postoperative CIN. We reviewed the incidence of pre-procedural glucose and postoperative CIN in 532 patients with CAG/PCI from June 1, 2020 to January 31, 2021 in Tianjin Chest Hospital, and divided the preoperative pre-procedural glucose levels into 5 groups. Blood samples were collected at admission, $48 \mathrm{~h}$ and $72 \mathrm{~h}$ after operation to measure the serum creatinine (Scr) value of patients. We found Patients with elevated pre-procedural glucose had higher BMl, and they were more often on therapy with PCl. They also had higher basal, 24h and 48h Scr. (Table 1) The incidence of CIN in the 5 groups of patients were: $6.9 \%, 10.7 \%, 14.1 \%, 20.1 \%, 26.0 \%$. $(p=0.030)$ The multivariate analysis confirmed that in the main high-risk subgroup, patients with elevated pre-procedural glucose levels $(\geq$ $158 \mathrm{mg} / \mathrm{dl}$ ) had a higher risk of CIN disease. (Fig. 2) Trend test showed the change of HR $(1.000,1.646$, $2.285,3.227,4,788$ ). (Table 2 ) We come to the conclusion that in diabetic patients undergoing $\mathrm{CAG} / \mathrm{PCl}$, elevated pre-procedural glucose is independently associated with the risk of $\mathrm{CIN}$, and with the increase of pre-procedural glucose level, the incidence of CIN gradually increases.

\section{Introduction}

Contrast-induced nephropathy $(\mathrm{CIN})$ is reversible acute renal failure observed after administration of iodinated contrast media (CM) during angiographic or other medical procedures and is defined as an increase of $25 \%$ or more, or an absolute increase of $0.5 \mathrm{mg} / \mathrm{dL}$ or more in serum creatinine (Scr) from baseline value, at 48 to 72 hours following the exposure to CM. $(1,2)$ The exact mechanism of CIN is unclear, and it may be related to hemodynamic effects, the formation of reactive oxygen species (ROS) and renal tubular cytotoxicity. $(3,4)$ The incidence of $\mathrm{CIN}$ is not relatively high in patients with normal renal function, but risk factors can enhance the morbidity of CIN. (5)Age, diabetes, contrast medium dosage, etc. have been confirmed to be closely related to the occurrence of CIN. Studies have found that patients with diabetes have a higher risk of CIN. Diabetic nephropathy has been identified as a powerful and independent risk factor for CIN. $(6,7)$ The key to reducing the incidence of $\mathrm{CIN}$ is to identify patients at high risk of $\mathrm{CIN}$ and to adopt appropriate prevention programs. Both diabetes and the administration of iodinated radiocontrast agents are both associated with marked alterations of renal physiology, including changes in GFR and renal hemodynamics, enhanced tubular transport activity and oxygen expenditure and intensification of medullary hypoxia, and ROS generation.(8) Hyperglycemia will cause many pathophysiological changes, such as endothelial and microvascular dysfunction, increased production of vascular inflammatory markers and ROS, and impaired immune response.(9) So far studies have confirmed that elevated pre-procedural glucose is associated with greater risk for $\mathrm{Cl}$-AKI in patients without known diabetes who undergo coronary angiography in the setting of acute myocardial infarction. (10)With the popularity of coronary angiography and the number of diabetic patients has increased, there is no more data to confirm whether the level of pre-procedural glucose in patients with existing diabetic 
patients affects the occurrence of $\mathrm{CIN}$. Therefore, compared with previous clinical trials, our study aims to focus on whether the level of pre-procedural glucose in diabetic patients undergoing CAG/PCI due to unstable angina is related to the risk of $\mathrm{CIN}$.

\section{Method}

\section{Ethics declarations}

Our experiment has been approved by the Medical Ethics Committee of Tianjin Chest Hospital and has been carried out in accordance with relevant naming guidelines and regulations.

We confirm that the informed consent of all participants was obtained prior to the experiment.

\section{Study population}

We initially assessed 629 patients who underwent CAG/PCI due to unstable angina or Non-ST segment myocardial infarction (NSTEMI). Inclusion criteria were as follows: Patients who meet the diagnostic criteria for diabetes and underwent CAG/PCI. [The American Diabetes Association (ADA) defines Criteria for the diagnosis of diabetes: (1) fasting plasma glucose (FPG) $>126 \mathrm{mg} / \mathrm{dL}(7.0 \mathrm{mmol} / \mathrm{L})$; (2)2h plasma glucose (PG) > $200 \mathrm{mg} / \mathrm{dL}$ (11.1 mmol/L) during oral glucose tolerance test (OGTT); (3) HbA1c > 6.5\% (48 $\mathrm{mmol} / \mathrm{mol}$ ); (4)In a patient with classic symptoms of hyperglycemia or hyperglycemic crisis, a random plasma glucose $>200 \mathrm{mg} / \mathrm{dL}(11.1 \mathrm{mmol} / \mathrm{L})]$.(14)Exclusion criteria were acute ST-segment elevation myocardial infarction (STEMI) receiving emergency $\mathrm{PCl}$, receiving $\mathrm{CM} 14$ days before $\mathrm{PCl}$, using any renal toxicity drugs during the perioperative period, severe renal insufficiency (creatinine clearance $<30$ $\mathrm{mL} / \mathrm{min}$ ) or severe cardiac insufficiency (left ventricular ejection fraction (LVEF) $<30 \%$ ), cardiogenic shock and heart failure, hypersensitivity to $\mathrm{CM}$, severe liver damage, autoimmune diseases, malignant tumor, infectious diseases or fever.(Fig. 1)

\section{Study protocol}

We finally evaluated 532 diabetic patients undergoing CAG/PCl. All patients were given a diabetic diet after admission, and hypoglycemic drugs and insulin were applied according to the individual situation. They were given aspirin and clopidogrel loading dose $300 \mathrm{mg}$ before operation. Clinicians can decide whether to use the following medicines based on clinical requirements or guidelines, including b-blockers, angiotensin converting enzyme inhibitors (ACEls)/angiotensin II receptor blockers (ARBs), calcium channel blockers (CCBs), diuretics, and statin. Blood glucose was collected 30 minutes before operation. Patients were stratified into 5 pre-procedural glucose groups: $<126 \mathrm{mg} / \mathrm{dl}(\mathrm{n}=29) ; 126$ to $150 \mathrm{mg} / \mathrm{dl}(\mathrm{n}=84)$; 151 to $175 \mathrm{mg} / \mathrm{dl}(\mathrm{n}=163) ; 176$ to $200 \mathrm{mg} / \mathrm{dl}(\mathrm{n}=179) ;>200 \mathrm{mg} / \mathrm{dl}(\mathrm{n}=77)$. Because related studies have proved that hydration in the perioperative period is effective in preventing the occurrence of $\mathrm{CIN}(11)$, all patients received isotonic saline ( $0.9 \%$ sodium chloride) 12 hours before and after surgery and supplemented with standard hydration solution (at least $1,000 \mathrm{~mL}$ ) at a rate of $1 \mathrm{~mL} / \mathrm{kg} / \mathrm{h}$. Hydration rate was reduced to $0.5 \mathrm{~mL} / \mathrm{kg} / \mathrm{h}$ for patients with $\mathrm{LVEF} \leqslant 45 \%$. All patients were treated with iodoprolamide contrast agent during the operation.(12) 


\section{Study endpoints}

Blood samples were collected at admission, $48 \mathrm{~h}$ and $72 \mathrm{~h}$ after operation to measure the Scr value of patients. The primary study end point was CIN, diagnosed by the highest Scr concentrations 48 and 72 hours after $\mathrm{CM}$ exposure. Additional clinical endpoints included: Adverse events during hospitalization and 14-day follow-up (A total of 529 people were followed up), included all-cause mortality, hypotension or severe decrease in blood pressure, acute heart failure, coronary artery bypass, and graft cerebrovascular events. There was no statistical difference in the number of adverse events among the five groups of patients. $(P=0.771)$

\section{Statistical analysis}

We determined the sample size based on previous studies. Results are expressed as numbers (\%) or mean \pm SD. Compare means between five groups: categorical variables were compared using a chisquare test, and continuous variables were compared using an analysis of variance. Fisher's exact test was used to compare the percentages when the expected frequency was less than 5 . Multivariable logistic regression analysis was used to exclude the influence of confounding factors, and to evaluate whether the association between pre-procedural glucose values and $\mathrm{CIN}$ persisted after adjustment for other patient characteristics and potential confounders. P for trend was used to analyze the trend between pre-procedural glucose levels and the increased risk of CIN. All statistical data were analyzed by SPSS software 22.0.

\section{Results}

\section{Baseline clinical characteristics}

There were no significant differences between the five groups in the baseline characteristics (Age, Male, Smoking, LVEF, Hypertension, Contrast volume, TG, TC, HDL-C, LDL-C, Hydration amount, b-blockers, ACEI/ARB, Diuretics, CCBs) before operation. Patients with elevated pre-procedural glucose levels had higher BMI $(p=0.005)$. In addition, patients with higher levels of glucose were more often on therapy with PCl. $(p=0.049)($ Table 1$)$ 
Table 1

Comparisons of baseline characteristics between the five groups.

\begin{tabular}{|llllll|}
\hline Variables & GLU & GLU & GLU & GLU & GLU \\
& $<$ & 126 & 151 & 176 to & $>$ \\
& $126 \mathrm{mg} / \mathrm{dl}$ & to150mg/dl & to175mg/dl & $200 \mathrm{mg} / \mathrm{dl}(\mathrm{n}=$ & $200 \mathrm{mg} / \mathrm{dl}$ \\
& $(n=29)$ & $(n=84)$ & $(n=163)$ & $179)$ & $(n=77)$
\end{tabular}




\begin{tabular}{|c|c|c|c|c|c|c|}
\hline Variables & $\begin{array}{l}\text { GLU } \\
< \\
126 \mathrm{mg} / \mathrm{dl} \\
(n=29)\end{array}$ & $\begin{array}{l}\text { GLU } \\
126 \\
\text { to } 150 \mathrm{mg} / \mathrm{dl} \\
(n=84)\end{array}$ & $\begin{array}{l}\text { GLU } \\
151 \\
\text { to175mg/dl } \\
(n=163)\end{array}$ & $\begin{array}{l}\text { GLU } \\
176 \text { to } \\
200 \mathrm{mg} / \mathrm{dl}(\mathrm{n}= \\
179)\end{array}$ & $\begin{array}{l}\text { GLU } \\
200 \mathrm{mg} / \mathrm{dl} \\
(n=77)\end{array}$ & $\mathbf{P}$ \\
\hline Age (years) & $65.86 \pm$ & $66.89 \pm$ & $67.62 \pm$ & $67.16 \pm 7.43$ & $68.58 \pm$ & 0.345 \\
\hline Male (\%) & $16(55.2)$ & $40(47.6)$ & $91(55.8)$ & $86(48.0)$ & $40(51.9)$ & 0.605 \\
\hline Smoking (\%) & $20(67.0)$ & $53(63.1)$ & $116(71.2)$ & 107(59.8) & $50(64.9)$ & 0.268 \\
\hline $\begin{array}{l}\text { LVEF } \\
\text { Hypertension }\end{array}$ & $\begin{array}{l}60.59 \pm \\
8.17\end{array}$ & $\begin{array}{l}60.42 \pm \\
6.96\end{array}$ & $\begin{array}{l}59.56 \pm \\
7.07\end{array}$ & $\begin{array}{l}60.73 \pm 7.02 \\
101(56.4)\end{array}$ & $\begin{array}{l}59.26 \pm \\
7.18\end{array}$ & $\begin{array}{l}0.611 \\
0.452\end{array}$ \\
\hline & $15(51.7)$ & $49(92.2)$ & $78(47.9)$ & $24.78 \pm 2.00$ & $43(55.8)$ & $0.005^{\star}$ \\
\hline $\begin{array}{l}\text { BMI }\left(\mathrm{kg} / \mathrm{m}^{2}\right) \\
\text { Contrast }\end{array}$ & $\begin{array}{l}23.76 \pm \\
2.04\end{array}$ & $\begin{array}{l}23.98 \pm \\
2.08\end{array}$ & $\begin{array}{l}24.63 \pm \\
2.12\end{array}$ & $177.0 \pm 59.06$ & $\begin{array}{l}24.84 \pm \\
2.06\end{array}$ & 0.366 \\
\hline $\begin{array}{l}\text { volume }(\mathrm{mL}) \\
\text { TG (mmol/L) }\end{array}$ & $\begin{array}{l}168.6 \pm \\
41.55\end{array}$ & $\begin{array}{l}165.2 \pm \\
49.44\end{array}$ & $\begin{array}{l}174.5 \pm \\
59.79\end{array}$ & $\begin{array}{l}1.90 \pm 1.15 \\
4.58 \pm 0.56\end{array}$ & $\begin{array}{l}182.7 \pm \\
65.43\end{array}$ & $\begin{array}{l}0.566 \\
0.538\end{array}$ \\
\hline $\mathrm{TC}(\mathrm{mmol} / \mathrm{L})$ & $\begin{array}{l}1.84 \pm \\
1.04\end{array}$ & $1.69 \pm 0.97$ & $1.76 \pm 0.91$ & $1.25 \pm 0.25$ & $\begin{array}{l}1.76 \pm \\
0.88\end{array}$ & 0.425 \\
\hline $\begin{array}{l}\mathrm{HDL}-\mathrm{C} \\
(\mathrm{mmol} / \mathrm{L})\end{array}$ & $\begin{array}{l}4.62 \pm \\
0.41\end{array}$ & $\begin{array}{l}4.52 \pm 0.38 \\
1.26 \pm 0.33\end{array}$ & $\begin{array}{l}4.53 \pm 0.43 \\
1.24 \pm 0.33\end{array}$ & $\begin{array}{l}2.48 \pm 0.52 \\
1274.4 \pm\end{array}$ & $\begin{array}{l}4.50 \pm \\
0.48\end{array}$ & $\begin{array}{l}0.793 \\
0.259\end{array}$ \\
\hline $\begin{array}{l}\text { LDL-C } \\
(\mathrm{mmol} / \mathrm{L})\end{array}$ & $\begin{array}{l}1.29 \pm \\
0.47\end{array}$ & $2.54 \pm 0.61$ & $2.49 \pm 0.58$ & $160(89.4)$ & $\begin{array}{l}1.33 \pm \\
0.55\end{array}$ & 0.077 \\
\hline $\begin{array}{l}\text { Hydration } \\
\text { amount }(\mathrm{mL})\end{array}$ & $\begin{array}{l}2.50 \pm \\
0.69\end{array}$ & $\begin{array}{l}1340.6 \pm \\
267.91\end{array}$ & $\begin{array}{l}1315.2 \pm \\
236.53\end{array}$ & $95(53.1)$ & $\begin{array}{l}2.57 \pm \\
0.54\end{array}$ & $\begin{array}{l}0.472 \\
0.963\end{array}$ \\
\hline $\begin{array}{l}\beta \text {-antagonist } \\
(\%)\end{array}$ & $\begin{array}{l}1318.6 \pm \\
266.92\end{array}$ & $\begin{array}{l}70(83.3) \\
43(51.2)\end{array}$ & $\begin{array}{l}131(80.4) \\
71(43.6)\end{array}$ & $\begin{array}{l}25(14.0) \\
155(86.6)\end{array}$ & $\begin{array}{l}1307.1 \pm \\
255.91\end{array}$ & 0.168 \\
\hline ACEI/ARB (\%) & $21(72.4)$ & 10(11.9) & 19(11.7) & $79(44.1)$ & $65(84.4)$ & 0.750 \\
\hline CCB (\%) & $15(51.7)$ & $62(73.8)$ & 134(82.2) & $96(53.6)$ & $40(51.9)$ & $0.049^{\star}$ \\
\hline $\begin{array}{l}\text { Hypoglycemic } \\
\text { agents (\%) }\end{array}$ & $3(7.8)$ & $32(38.1)$ & $61(72.6)$ & $102.8 \pm 11.44$ & 10(13.0) & $0.005^{\star}$ \\
\hline Insulin (\%) & $24(82.8)$ & $36(42.9)$ & $78(47.9)$ & $118.1 \pm 16.07$ & $63(81.8)$ & $0.000^{\star}$ \\
\hline $\mathrm{PCl}(\%)$ & 11(37.9) & $\begin{array}{l}102.07 \pm \\
14.61\end{array}$ & $\begin{array}{l}101.78 \pm \\
15.01\end{array}$ & $115.3 \pm 15.09$ & $30(40.0)$ & $0.000^{*}$ \\
\hline $\begin{array}{l}\text { Basal Scr } \\
(\mathrm{mmol} / \mathrm{L}) \\
48 \mathrm{~h}\end{array}$ & $\begin{array}{l}10(34.5) \\
98.92 \pm \\
14.53\end{array}$ & $\begin{array}{l}114.7 \pm \\
18.48\end{array}$ & $\begin{array}{l}114.6 \pm \\
17.69\end{array}$ & & $\begin{array}{l}47(61.0) \\
108.1 \pm \\
14.08\end{array}$ & \\
\hline $\begin{array}{l}\text { Scr }(\mathrm{mmol} / \mathrm{L}) \\
72 \mathrm{~h} \mathrm{Scr} \\
(\mathrm{mmol} / \mathrm{L})\end{array}$ & $\begin{array}{l}110.6 \pm \\
11.92\end{array}$ & $\begin{array}{l}110.1 \pm \\
17.36\end{array}$ & $\begin{array}{l}109.0 \pm \\
17.23\end{array}$ & & $\begin{array}{l}126.8 \pm \\
13.86\end{array}$ & \\
\hline
\end{tabular}




\begin{tabular}{|c|c|c|c|c|c|c|}
\hline \multirow[t]{3}{*}{ Variables } & GLU & GLU & GLU & GLU & GLU & $P$ \\
\hline & $\begin{array}{l}< \\
126 \mathrm{mg} / \mathrm{dl} \\
(\mathrm{n}=29)\end{array}$ & $\begin{array}{l}126 \\
\text { to } 150 \mathrm{mg} / \mathrm{dl} \\
(\mathrm{n}=84)\end{array}$ & $\begin{array}{l}151 \\
\text { to } 175 \mathrm{mg} / \mathrm{dl} \\
(\mathrm{n}=163)\end{array}$ & $\begin{array}{l}176 \text { to } \\
200 \mathrm{mg} / \mathrm{dl}(\mathrm{n}= \\
179)\end{array}$ & $\begin{array}{l}200 \mathrm{mg} / \mathrm{dl} \\
(\mathrm{n}=77)\end{array}$ & \\
\hline & $\begin{array}{l}107.3 \pm \\
12.84\end{array}$ & & & & $\begin{array}{l}118.6 \pm \\
14.42\end{array}$ & \\
\hline
\end{tabular}

Table 1. Data are expressed as mean $\pm S D$ or $n(\%)$. ACEl: angiotensin-converting enzyme inhibitor; ARB: angiotensin receptor blocker; BMI: body mass index; TC: total cholesterol; TG: triglyceride; HDL-C: highdensity lipoprotein cholesterol; LDL-C: low-density lipoprotein cholesterol; LVEF: left ventricular ejection fraction; CCB: calcium channel blockers; PCl: Percutaneous Coronary Intervention.

\section{Comparison of Scr level and CIN incidence in each group}

Patients with elevated pre-procedural glucose had higher basal Scr $(p=0.005)$, higher Scr values at $48 \mathrm{~h}$ and $72 \mathrm{~h}$ after $\mathrm{CAG} / \mathrm{PCl}(\mathrm{p}<0.0001$, Table 1$)$. Multivariable logistic regression analysis was used to analyze the factors affecting $\mathrm{CIN}$. CIN was taken as the dependent variable, and factors that may affect the development of CIN (male, age, Contrast volume, Hydration amount, BMI, Hypertension, PCl) were taken as independent variables. CIN was used as the dependent variable to exclude confounding factors. $(\mathrm{OR}=1.008(1.001-1.015), p=0.033)$

The multivariate analysis confirmed the association between pre-procedural glucose and the risk of CIN after adjustment for baseline confounding factors. The results showed that patients with elevated preprocedural glucose (above the median value $158 \mathrm{mg} / \mathrm{dl}$ ) in the main high-risk subgroup had a higher risk of $\mathrm{CIN}$, such as $\mathrm{BMI}\left(\mathrm{BMI}>23.9 \mathrm{~kg} / \mathrm{m}^{2}\right.$ : adjusted $\mathrm{OR}=1.460(0.722-2.953), \mathrm{p}=0.292 ; \mathrm{BMI} \leq 23.9 \mathrm{~kg} / \mathrm{m}^{2}$ : adjusted $O R=5.517(1.576-19.315), p=0.008)$, Age (Age $\geq 65:$ adjusted $O R=2.947(1.285-6.761), p=$ 0.011; Age < 65: adjusted OR = 1.871(0.762-4.596), $\mathrm{p}=0.172), \mathrm{PCl}(\mathrm{PCl}$ : adjusted $\mathrm{OR}=2.983(1.212-$ 7.343), $\mathrm{p}=0.017$; No PCl: adjusted $\mathrm{OR}=1.654(0.714-3.843), \mathrm{p}=0.240)$.(Fig. 2)

The trend test was used to further demonstrate the relationship between pre-procedural glucose levels and CIN incidence. It can be seen from the changes in Hazard Ratio (HR) $(1.000,1.646,2.285,3.227,4.788)$, with the increase of pre-procedural glucose levels, the incidence of $\mathrm{CIN}$ increases gradually with a significant trend $(p<0.0001)$. (Table 2$)$ 
Table 2

The logistic regression analysis and the trend test

\begin{tabular}{|c|c|c|c|c|c|}
\hline \multirow[t]{2}{*}{ Blood glucose } & \multirow{2}{*}{$\begin{array}{l}\text { Participants, } \\
\text { n }\end{array}$} & \multirow{2}{*}{$\begin{array}{l}\text { CIN, } \\
\mathrm{n}\end{array}$} & \multicolumn{3}{|c|}{ Adjusted Hazard Ratio } \\
\hline & & & Model 1 & Model 2 & Model 3 \\
\hline $\mathrm{GLU}<126 \mathrm{mg} / \mathrm{dl}$ & 29 & 2 & 1.000(Reference) & 1.000(Reference) & 1.000(Reference) \\
\hline $\begin{array}{l}\text { GLU126 } \\
\text { to150mg/dl }\end{array}$ & & 9 & $\begin{array}{l}1.620(0.329- \\
7.976)\end{array}$ & $\begin{array}{l}1.660(0.332- \\
8.301)\end{array}$ & $\begin{array}{l}1.646(0.331- \\
8.180)\end{array}$ \\
\hline $\begin{array}{l}\text { GLU151 } \\
\text { to175mg/dl }\end{array}$ & $\begin{array}{l}163 \\
179\end{array}$ & $\begin{array}{l}23 \\
36\end{array}$ & $\begin{array}{l}2.331(0.520- \\
10.449)\end{array}$ & $\begin{array}{l}2.368(0.520- \\
10.783)\end{array}$ & $\begin{array}{l}2.285(0.503- \\
10.377)\end{array}$ \\
\hline $\begin{array}{l}\text { GLU176 to } \\
200 \mathrm{mg} / \mathrm{dl}\end{array}$ & 77 & 20 & $\begin{array}{l}3.399(0.772- \\
14.961)\end{array}$ & $\begin{array}{l}3.250(0.726- \\
14.549)\end{array}$ & $\begin{array}{l}3.227(0.724- \\
14.394)\end{array}$ \\
\hline $\mathrm{GLU}>200 \mathrm{mg} / \mathrm{dl}$ & & & $\begin{array}{l}4.737(1.032- \\
21.744)\end{array}$ & $\begin{array}{l}4.710(1.004- \\
22.096)\end{array}$ & $\begin{array}{l}4,788(1.026- \\
22.351)\end{array}$ \\
\hline$r$ & & & $<0.0001^{*}$ & $<0.0001^{*}$ & $<0.0001^{*}$ \\
\hline
\end{tabular}

Table 2. Model 1 was not adjusted. Model 2 was adjusted for male, hypertension, LVEF, hydration amount and $\mathrm{PCl}$. Model 3 additionally was adjusted for BMI.

\section{Discuss}

In this study, we evaluated the relationship between preoperative pre-procedural glucose level and CIN incidence in patients undergoing CAG/PCI. This controlled trial showed that in diabetic patients undergoing $\mathrm{CAG} / \mathrm{PCl}$, elevated pre-procedural glucose is independently associated with the risk of $\mathrm{CIN}$, and with the increase of pre-procedural glucose level, the incidence of CIN gradually increases. These results are of clinical significance, because Type 2 diabetes mellitus (T2DM) is a major risk factor affecting coronary artery disease (CAD), despite significant advances in the treatment of cardiovascular disease over the past 20 years, cardiovascular disease remains the leading cause of morbidity and mortality in patients with Type 2 diabetes mellitus, 75\% of T2DM patients die as a consequence of cardiovascular diseases. (13-15) With the improvement of PCl-related technology and equipment, $\mathrm{PCl}$ indications have become more extensive and complex, and the amount of surgery has increased year by year.(16)Patients who develop CIN have a greater risk for a number of non-renal complications including cardiac, vascular and systemic problems. For patients who develop CIN, treatment is limited to supportive measures until renal impairment resolves. It is important to evaluate the patient's blood glucose control before surgery and prevent postoperative $\mathrm{CIN}$, which not be viewed as a treatable and acceptable complication of contrast procedures. (17)

Diabetes is an important predisposing factor for $\mathrm{CIN}$, particularly in patients with renal functional impairment. Renal hypoxia, combined with the generation of reactive oxygen species, plays a central role in the pathogenesis of $\mathrm{CIN}$, and the diabetic kidney is particularly susceptible to intensified hypoxic and oxidative stress following the administration of contrast media. This complex pathophysiological 
mechanism includes a priori enhanced tubular transport activity, oxygen consumption, and the generation of reactive oxygen species. The regulation of vascular tone and peritubular blood flow may also be altered. In addition, microvascular and macrovascular diseases and chronic tubulointerstitial changes further compromise regional oxygen delivery, and renal antioxidant capacity might be hampered. In brief, both diabetes and contrast agents enhance ROS formation. They also hamper renal oxygenation, either directly or through increased generation of ROS.(17)The rat experiment showed that the CM-induced changes in diabetic rats indicate impaired renal function, oxidative stress, vascular dysfunction, and apoptosis, and were significance higher in intensity compared to non-diabetic rats.(19)Clinical studies have proven that for patients with known and unknown diabetes, elevated blood glucose levels and glycosylated hemoglobin before surgery are a powerful and independent risk factor for CIN.(10, 20)On this basis, we further studied whether pre-procedural glucose level also has an impact on CIN occurrence in diabetic patients, and obtained positive results.

\section{Limitations}

Our research excluded patients with severe renal insufficiency, receiving CM 14 days before operation, severe cardiac insufficiency, heart failure, malignant tumor, fever, and emergency PCl. Further studies on the pathogenesis and preventive measures are needed to completely prevent $\mathrm{CIN}$.

\section{Conclusions}

Studies have shown that in diabetic patients undergoing CAG/PCl, elevated pre-procedural glucose is independently associated with the risk of $\mathrm{CIN}$, and with the increase of pre-procedural glucose level, the incidence of CIN gradually increases. We consider that for patients with diabetes, controlling preprocedural glucose level has a preventive effect on postoperative $\mathrm{CIN}$, which is of great significance for patients undergoing elective $\mathrm{PCl}$.

\section{Declarations}

\section{Author contributions}

(I) Conception and design: Hong Zhang

(II) Administrative support: Naikuan Fu

(III) Provision of study materials or patients: Peng Zhang

(IV) Collection and assembly of data: Shicheng Yang

(V) Data analysis and interpretation: Han Fu

(VI) Manuscript writing: All authors 


\section{Competing interests:}

The author(s) declare no competing interests

\section{Data availability:}

All data in the article is available

\section{Ethics declarations:}

All procedures performed in research involving human participants comply with the ethical standards of the institution and/or the National Research Council, and comply with the 1964 Declaration of Helsinki and its subsequent amendments or similar ethical standards.

\section{Acknowledgements:}

we thank all the participants and enrolled patients of Tianjin Medical University in Tianjin of China for their cooperation. This study was funded by a Grant from the Tianjin Municipal Health and Family Planning Commission (Grant number: 14KG124).

\section{References}

1. Mamoulakis C, Tsarouhas K, Fragkiadoulaki I, Heretis I, Wilks MF, Spandidos DA, et al. Contrastinduced nephropathy: Basic concepts, pathophysiological implications and prevention strategies. Pharmacol Ther. [Journal Article; Review]. 2017 2017-12-01;180:99-112.

2. Mehran R, Nikolsky E. Contrast-induced nephropathy: Definition, epidemiology, and patients at risk. KIDNEY INT. 2006 2006-01-01;69:S11-5.

3. Seeliger E, Sendeski M, Rihal CS, Persson PB. Contrast-induced kidney injury: mechanisms, risk factors, and prevention. EUR HEART J. [Journal Article; Review]. 2012 2012-08-01;33(16):2007-15.

4. Geenen RWF, Kingma HJ, van der Molen AJ. Contrast-induced nephropathy: pharmacology, pathophysiology and prevention. Insights into Imaging. 2013;4(6):811-20.

5. Zhang F, Lu Z, Wang F. Advances in the pathogenesis and prevention of contrast-induced nephropathy. LIFE SCI. [Journal Article; Review]. 2020 2020-10-15;259:118379.

6. Mehran R, Aymong ED, Nikolsky E, Lasic Z, lakovou I, Fahy M, et al. A simple risk score for prediction of contrast-induced nephropathy after percutaneous coronary intervention: development and initial 
validation. J AM COLL CARDIOL. [Clinical Trial; Journal Article; Randomized Controlled Trial]. 2004 2004-10-06;44(7):1393-9.

7. Toprak O, Cirit M, Yesil M, Bayata S, Tanrisev M, Varol U, et al. Impact of diabetic and pre-diabetic state on development of contrast-induced nephropathy in patients with chronic kidney disease. NEPHROL DIAL TRANSPL. 2007 2007-01-05;22(3):819-26.

8. Deedwania P, Kosiborod M, Barrett E, Ceriello A, Isley W, Mazzone T, et al. Hyperglycemia and acute coronary syndrome: a scientific statement from the American Heart Association Diabetes Committee of the Council on Nutrition, Physical Activity, and Metabolism. CIRCULATION. [Journal Article]. 2008 2008-03-25;117(12):1610-9.

9. Heyman SN, Rosenberger C, Rosen S, Khamaisi M. Why Is Diabetes Mellitus a Risk Factor for Contrast-Induced Nephropathy? BIOMED RES INT. 2013;2013:1-8.

10. Stolker JM, McCullough PA, Rao S, Inzucchi SE, Spertus JA, Maddox TM, et al. Pre-Procedural Glucose Levels and the Risk for Contrast-Induced Acute Kidney Injury in Patients Undergoing Coronary Angiography. J AM COLL CARDIOL. 2010;55(14):1433-40.

11. Nijssen EC, Rennenberg RJ, Nelemans PJ, Essers BA, Janssen MM, Vermeeren MA, et al. Prophylactic hydration to protect renal function from intravascular iodinated contrast material in patients at high risk of contrast-induced nephropathy (AMACING): a prospective, randomised, phase 3, controlled, open-label, non-inferiority trial. LANCET. [Clinical Trial, Phase III; Journal Article; Randomized Controlled Trial; Research Support, Non-U.S. Gov't]. 2017 2017-04-01;389(10076):1312-22.

12. Subramaniam RM, Suarez-Cuervo C, Wilson RF, Turban S, Zhang A, Sherrod C, et al. Effectiveness of Prevention Strategies for Contrast-Induced Nephropathy: A Systematic Review and Meta-analysis. ANN INTERN MED. [Journal Article; Meta-Analysis; Research Support, U.S. Gov't, P.H.S.; Review; Systematic Review]. 2016 2016-03-15;164(6):406-16.

13. Das SR, Everett BM, Birtcher KK, Brown JM, Januzzi JL, Kalyani RR, et al. 2020 Expert Consensus Decision Pathway on Novel Therapies for Cardiovascular Risk Reduction in Patients With Type 2 Diabetes. J AM COLL CARDIOL. 2020;76(9):1117-45.

14. Naito R, Miyauchi K. Coronary Artery Disease and Type 2 Diabetes Mellitus. INT HEART J. [Journal Article; Review]. 2017 2017-08-03;58(4):475-80.

15. Genuth S, Alberti KG, Bennett P, Buse J, Defronzo R, Kahn R, et al. Follow-up report on the diagnosis of diabetes mellitus. DIABETES CARE. [Consensus Development Conference; Journal Article; Review]. 2003 2003-11-01;26(11):3160-7.

16. Bhatt DL. Percutaneous Coronary Intervention in 2018. JAMA. [Journal Article; Review]. 2018 201805-22;319(20):2127-8.

17. Finn WF. The clinical and renal consequences of contrast-induced nephropathy. NEPHROL DIAL TRANSPL. 2006 2006-06-01;21(suppl_1):i2-10.

18. Andreucci M, Faga T, Pisani A, Sabbatini M, Michael A. Acute Kidney Injury by Radiographic Contrast Media: Pathogenesis and Prevention. BIOMED RES INT. 2014;2014:1-21. 
19. Hussien NI, Sorour SM, El-kerdasy HI, Abdelrahman BA. The glucagon-like peptide-1 receptor agonist Exendin-4, ameliorates contrast-induced nephropathy through suppression of oxidative stress, vascular dysfunction and apoptosis independent of glycaemia. CLIN EXP PHARMACOL P. 2018;45(8):808-18.

20. Barbieri L, Verdoia M, Schaffer A, Cassetti E, Di Giovine G, Marino P, et al. Pre-diabetes and the risk of contrast induced nephropathy in patients undergoing coronary angiography or percutaneous intervention. DIABETES RES CLIN PR. 2014;106(3):458-64.

\section{Figures}

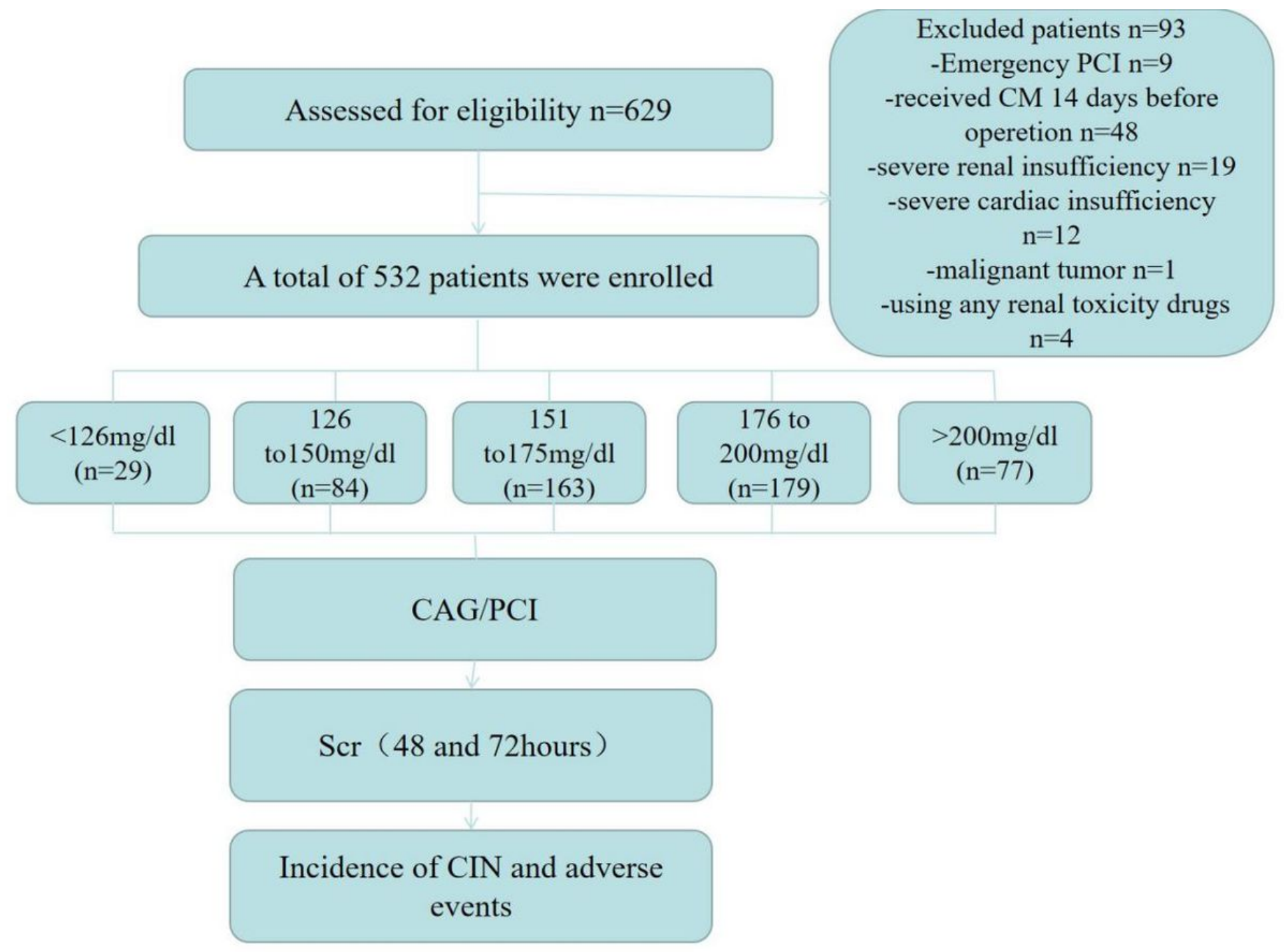

\section{Figure 1}

CAG: Coronary arteriography PCl; percutaneous coronary intervention; Scr: serum creatinine; CIN: contrastinduced nephropathy 


\section{Risk of CIN \\ OR $[95 \% \mathrm{Cl}]$}

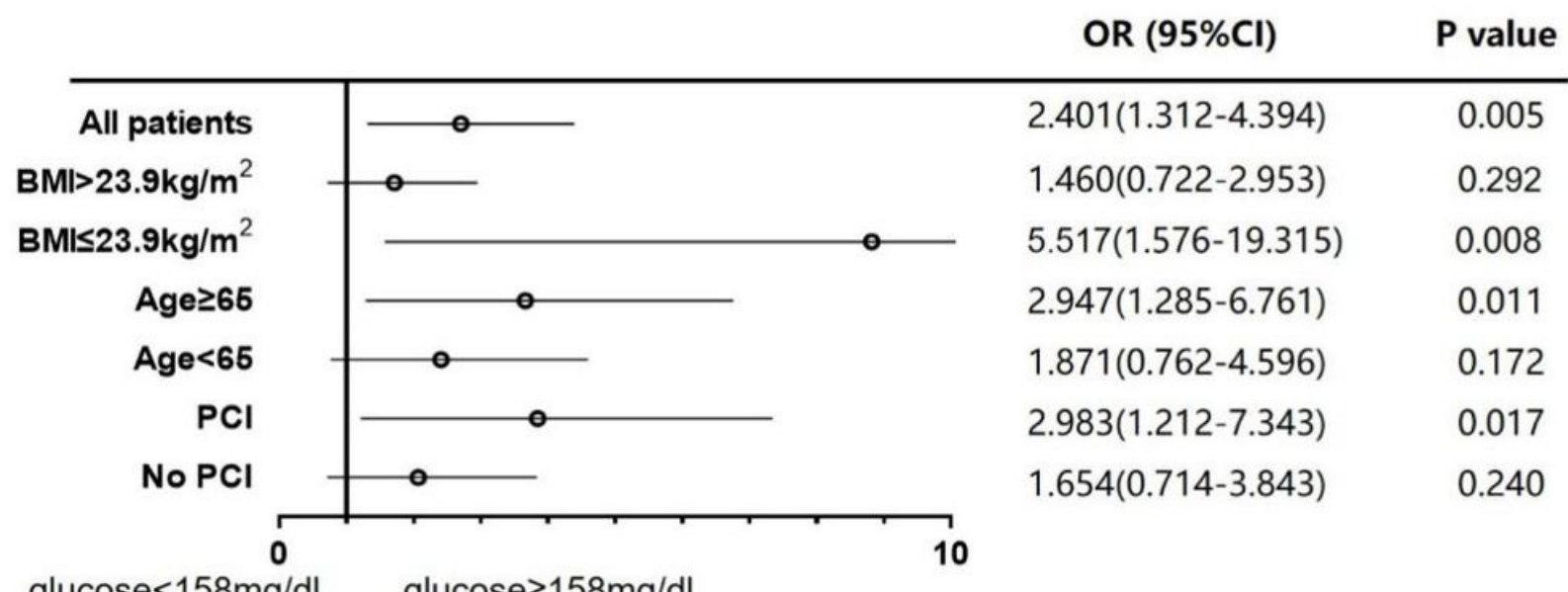

glucose $<158 \mathrm{mg} / \mathrm{dl} \quad$ glucose $\geq 158 \mathrm{mg} / \mathrm{dl}$

\section{Figure 2}

$158 \mathrm{mg} / \mathrm{dl}$ is the median elevated pre-procedural glucose levels. BMl: body mass index; PCl: Percutaneous Coronary Intervention.

\section{Supplementary Files}

This is a list of supplementary files associated with this preprint. Click to download.

- Supplementarylnformation.pdf 